\title{
MoniKa GŁaDOCH
}

Uniwersytet Kardynała Stefana Wyszyńskiego

\author{
ZNACZENIE KONTROLI \\ PAŃSTWOWEJ INSPEKCJI PRACY \\ DLA OCHRONY ŻYCIA I ZDROWIA PRACOWNIKÓW
}

\section{WPROWADZENIE}

Państwowa Inspekcja Pracy - z racji swoich funkcji - pełni kluczową rolę w sprawowaniu kontroli nad przestrzeganiem norm prawa pracy. Mimo że nie wchodzi w skład struktury wymiaru sprawiedliwości, okazuje się najskuteczniejszym organem w zakresie nadzoru nad przestrzeganiem prawa przez pracodawców. PIP jest powszechnie postrzegana jako instytucja gwarantująca najszybszą i najskuteczniejszą pomoc dla pracowników. Z uwagi na fakt, że czas postępowania kontrolnego w porównaniu $\mathrm{z}$ okresem trwania procesu wydaje się bardzo krótki, pracownik nierzadko najpierw zwraca się o pomoc do inspekcji, a dopiero po zasięgnięciu opinii lub przeprowadzeniu postępowania kontrolnego występuje na drogę sądową. Od lat można zaobserwować utrzymującą się tendencję do powierzenia inspekcji coraz to nowych obowiązków kontrolnych. I tak, z organu kontroli nad warunkami pracy inspekcja stała się instytucją nadzorującą wszelkie zjawiska istniejące na rynku pracy, włącznie z kontrolą spraw niewiążących się z ochroną pracy, na przykład spełniania obowiązków, o których mowa w ustawie 
z 10 kwietnia 1997 r. - Prawo energetyczne ${ }^{1}$ w zakresie paliw ciekłych. Obserwowany trend wynika zapewne z potrzeby kontroli nowych zjawisk na rynku pracy, a ponadto $z$ deficytu innych organów państwowych mających uprawnienia audytorskie.

Celem tego opracowania jest próba oceny uprawnień PIP z punktu widzenia podstawowej potrzeby ochrony życia i zdrowia pracowników. Niezbędna wydaje się refleksja na temat przyszłości inspekcji jako organu kontrolnego, jak również dokonanie oceny roli, jaką inspekcja powinna pełnić na rynku pracy - czy ma być organem policyjnym, czy raczej podmiotem doradczym i wspierającym pracodawców w wykonywaniu ich obowiązków związanych z zatrudnieniem. Dalsze rozważania w tym zakresie warto poprzedzić cytatem z wystąpienia Głównego Inspektora Pracy Mariana Klotta, wygłoszonego w Warszawie w 1937 r. w Polskim Towarzystwie Polityki Społecznej. Powiedział on wówczas: „Inspekcja pracy z tytułu genezy swego pochodzenia i swych zadań istotnych jest może najbardziej czułą, wysuniętą w przyszłość nieznanych zjawisk społecznych, komórką organizmu państwowego, która rejestruje i rozstrzyga niezbadane jeszcze zjawiska najtrudniejszego odcinka życia zbiorowego - odcinka podziału dóbr społecznych, podziału dochodu społecznego"2.

2. UpRaWNiENia PIP DO CZASU UCHWALENIA USTAWy Z 2007 R.

W okresie dwudziestolecia międzywojennego wyrażano powszechne zrozumienie dla potrzeby powołania organu państwowego, którego zadaniem miała być kontrola warunków pracy. Cytowany wcześniej M. Klott pisał o konieczności „wtrącania się państwa do swobodnych stosunków pomiędzy pracą a kapitałem, pomiędzy kupującym pracę przemysłowcem a sprzedającym swą pracę robotnikiem"3. Początek inspekcji pracy w Polsce datuje się od dnia wejścia w życie dekretu

Tekst jedn.: Dz. U. z 2017 r. poz. 220.

A. Mazurkiewicz, Czego nas uczq wypadki przy pracy, Warszawa 1957, s. 8.

M. Kцотт, Inspekcja pracy w Polsce, Warszawa 1937, s. 24. 
tymczasowego o urządzeniu i działalności inspekcji pracy, który został opublikowany w Dzienniku Praw Państwa Polskiego z 13 stycznia 1919 r. ${ }^{4}$ Kompetencje inspektorów pracy zostały uregulowane w art. 11 dekretu. Dotyczyły one nadzoru nad zakładami pracy, łącznie z egzekwowaniem przestrzegania przepisów ochronnych. Wiele obowiązków wynikało z ustaw odrębnych. Niestety, nie zawsze były one związane z uprawnieniami kontrolnymi, lecz obejmowały na przykład obowiązki statystyczne 5 .

Dalszy rozwój inspekcji nastąpił wraz z uchwaleniem rozporządzenia Prezydenta Rzeczypospolitej z 14 lipca 1927 r. o inspekcji pracy ${ }^{6}$, kiedy powołano odrębny organ administracji państwowej, niezespolony z władzami administracji ogólnej. Na mocy art. 3 inspekcja pracy była obowiązana i uprawniona do nadzoru nad przestrzeganiem i wykonaniem przepisów prawa o ochronie pracy, a w szczególności o ochronie życia, zdrowia i sił pracowników, o przestrzeganiu dobrych obyczajów w stosunkach pracy, o umowie pracy, o zbiorowych umowach pracy, o regulaminie pracy, o czasie pracy, o dniach świątecznych, o urlopach, o pracy młodocianych i umożliwianiu im kształcenia się ogólnego i zawodowego, o pracy kobiet, o przedstawicielstwie pracowników i jego uprawnieniach, o pracy chałupniczej. Inspekcja uczestniczyła także w czynnościach dotyczących pozwoleń na otwarcie lub przebudowę zakładów przemysłowych ze względu na higienę i bezpieczeństwo pracy, jak również występowała jako oskarżyciel przed sądami pokoju, obok innych organów publicznych w sprawach o nieprzestrzeganie przepisów o ochronie pracy. Już pobieżny przegląd uprawnień inspekcji pokazuje, że od początku swojego powstania była ona organem wyposażonym w liczne kompetencje kontrolne, a nawet procesowe. Istotnie wzmocniono uprawnienia nadzorcze inspektorów pracy poprzez przyznanie im prawa wydawania wiążących nakazów (a nie jak uprzednio - tylko

\footnotetext{
Dz. Pr. P.P. Nr 5 z 1919 r., poz. 90.

Por. T. KozŁowski, Geneza Państwowej Inspekcji Pracy - uprawnienia inspektora pracy wczoraj i dziś, [w:] Nauka i praktyka w służbie człowiekowi pracy: Inspekcja pracy - wyzwania przyszłości, red. A. MusiaŁa, Poznań 2017, s. 16.

6 Dz. U. Nr 67, poz. 590.
} 
zaleceń), które stały się podstawowym środkiem działania inspekcji Pierwsze lata funkcjonowania inspekcji wykazywały permanentne łamanie prawa pracy w zakresie przestrzegania czasu pracy, urlopów, wypłat wynagrodzeń, a także zatrudniania młodocianych i dzieci. Sytuacja uległa poprawie dopiero w latach 30., kiedy inspekcja otrzymała prawo wydawania nakazów i zaczęły funkcjonować sądy pracy ${ }^{8}$.

Polska regulacja z 1927 r. stanowiła zarazem odpowiedź na postulaty Międzynarodowej Organizacji Pracy, które zostały zawarte w uchwale sesji międzynarodowej konferencji pracy z 1923 r. Zapisano w niej między innymi: „Zasadniczym zadaniem inspekcji, którą każdy członek winien zorganizować, zgodnie z zasadą wyrażoną w nrze 9 art. 427 traktatu wersalskiego, jest zapewnienie stosowania ustaw i rozporządzeń, dotyczących warunków pracy i ochrony pracowników przy wykonywaniu pracy zawodowej (czas pracy i odpoczynku, pora nocna, zakaz zatrudniania pewnych kategorii osób przy robotach niebezpiecznych, szkodliwych dla zdrowia lub przekraczających ich siły, higiena i bezpieczeństwo itd.)".

W okresie PRL inspekcja pracy została znacznie rozbudowana. Zwiększono liczbę okręgowych i obwodowych inspektorów pracy, a także podinspektorów pracy. Zakres działania organów objął nadzór nad przestrzeganiem przepisów o bezpieczeństwie i higienie pracy, o pracy kobiet i młodocianych, o czasie pracy i urlopach oraz o umowie o pracę 9 . Inspekcja została jednak przekształcona w branżową techniczną inspekcję pracy, podporządkowaną Centralnej Radzie Związków Zawodowych, co trwało aż do lat 80. ubiegłego wieku. W 1965 r. przywrócono inspekcji jej dawną nazwę i poszerzono uprawnienia kontrolne w zakładzie pracy. W dalszym ciągu była zorganizowana według branż. W piśmiennictwie zwracano wówczas uwagę na niewielki zakres i częstotliwość kontroli, co wynikało przede wszystkim z niedoboru kadrowego wśród inspektorów pracy. Już wtedy dostrzegano problem wynikający ze słabszej kontroli

\footnotetext{
Por. M. Święcicki, Prawo pracy, Warszawa 1968, s. 48.

8 Por. szerzej J. Laskowski, Dorobek i kierunki doskonalenia działalności w zakresie ochrony pracy, [w:] 70 lat inspekcji pracy w Polsce, Warszawa 1989, s. 15.

9 Por. Inspekcja pracy w Polsce w latach 1954-1964. Sprawozdanie ze stanu bezpieczeństwa i higieny pracy, Warszawa 1967, s. 8.
} 
nad małymi zakładami. Pisano także o „szczupłości czasu, jaki może być poświęcony przez inspektora pracy na poszczególną wizytację"10. Kolejną ustawę uchwalono 6 marca 1981 r. o Państwowej Inspekcji Pracy"11, która przywróciła inspekcji charakter organu państwowego. Ustawa obowiązywała do czasu wejścia w życie obecnie obowiązującej ustawy z 13 kwietnia 2007 r. o Państwowej Inspekcji Pracy².

Warto zauważyć, że od ponad 100 lat inspekcja mierzy się z podobnymi nadużyciami na rynku pracy. Trudność jest jednak dużo większa, przede wszystkim z powodu dodania inspekcji nowych obowiązków, przy utrzymaniu dotychczasowej liczebności kadr.

\section{Zadania Inspekcji Pracy}

NA PODSTAWIE KONWENCJI MOP NR 81

Kluczowe znaczenie dla koncepcji działania inspekcji pracy odgrywają regulacje konwencji nr 81 MOP z 1947 r. dotyczącej inspekcji pracy w przemyśle i handlu ${ }^{13}$. Obok niej wymienia się także konwencję nr 129 z 1969 r. o inspekcji pracy w rolnictwie ${ }^{14}$. Warto podkreślić, że obie konwencje uznaje się za priorytetowe dla działalności MOP. W Globalnym pakcie na rzecz zatrudnienia z 2009 r. regulacje w dziedzinie inspekcji pracy uznano za niezwykle istotne w dobie globalnego kryzysu gospodarczego ${ }^{15}$.

Na mocy art. 3 do zadań systemu inspekcji pracy będzie należało: (a) zapewnianie stosowania przepisów prawnych dotyczących warunków pracy i ochrony pracowników przy wykonywaniu ich zawodu, takich jak postanowienia dotyczące czasu pracy, płac, bezpieczeństwa, zdrowia

10 Por. W. Schubert, Ochrona pracy. Studium społeczno-prawne, Warszawa 1966, s. 152.

11 Tekst jedn.: Dz. U. z 2001 r. Nr 124, poz. 1362 ze zm.

12 Tekst jedn.: Dz. U. z 2017 r. poz. 786 ze zm.

13 Dz. U. z 1997 r. Nr 72, poz. 450.

14 Dz. U. z 1997 r. Nr 72, poz. 452.

15 D. MAкоwsкi, Inspekcja pracy jako instytucja państwowego nadzoru nad przestrzeganiem prawa pracy, Łódź 2017, s. 35. 
i warunków socjalnych, zatrudnienia dzieci i młodocianych oraz innych spraw z tym związanych, w takim zakresie, w jakim inspektorzy pracy są zobowiązani do zapewnienia stosowania tych postanowień; (b) dostarczanie informacji i porad technicznych pracodawcom i pracownikom co do najskuteczniejszych sposobów przestrzegania przepisów prawnych; (c) zwracanie uwagi właściwej władzy na uchybienia lub nadużycia nieunormowane szczegółowo w istniejących przepisach prawnych. Na podstawie wymienionych zadań w piśmiennictwie wyodrębnione zostały cztery funkcje inspekcji pracy: 1) egzekucyjna, polegająca na zapewnieniu przepisów prawa pracy; 2) dostarczania informacji pracodawcom i pracownikom o obowiązujących przepisach prawa pracy; 3) sygnalizacyjna, związana z koniecznością informowania właściwych władz publicznych o dostrzeżonych przez inspektorów uchybieniach i nieprawidłowościach w stosowaniu prawa pracy; 4) działalność profilaktyczna (zapobiegawcza) ${ }^{16}$.

Co istotne, za kluczowe zadania inspekcji uważa się uprawnienia prewencyjne i korekcyjne, które wprost wynikają $\mathrm{z}$ art. 3 konwencji MOP nr 81. Inne natomiast traktowane są jako dodatkowe, jedynie uzupełniające. Na mocy art. 3 ust. 2 wskazanej konwencji inspektorom pracy mogą być powierzone jakiekolwiek inne obowiązki tylko pod warunkiem, że nie będą przeszkadzać w skutecznym wykonywaniu ich zadań głównych ani w jakikolwiek sposób naruszać autorytetu i bezstronności, potrzebnych inspektorom w stosunkach z pracodawcami i pracownikami. Nie ulega wątpliwości, że konwencja nr 81 MOP nie zezwala na zbyt szerokie kształtowanie uprawnień inspektorów pracy. W konsekwencji w literaturze dokonano jeszcze innego podziału zadań inspekcji. Wymienia się bowiem uprawnienia obligatoryjne i fakultatywne. Te drugie nie powinny zbyt mocno ingerować w zadania obowiązkowe, a tym samym ich ograniczać.

16 Por. D. Mакошsкi, Inspekcja pracy..., s. 157-158. 


\section{Zadania PIP na podstawie Konstytucji RP}

Państwowa Inspekcja Pracy wykonuje istotne zadania należące do państwa, nie jest jednak organem konstytucyjnym. Innymi słowy, PIP nie została wymieniona w ustawie zasadniczej. $Z$ tego powodu nie można przyjmować, że zadania inspekcji nie wynikają z Konstytucji. Wręcz przeciwnie. De lege lata należy dojść do wniosku, że inspekcja pracy czerpie swoją podstawę działania właśnie z norm konstytucyjnych. Dokonując przeglądu uprawnień inspekcji, należy mieć na uwadze przede wszystkim przepisy gwarantujące ochronę w zatrudnieniu. Podstawowym przepisem w tym zakresie jest art. 24 Konstytucji, zgodnie z którym praca znajduje się pod ochroną Rzeczypospolitej Polskiej. Państwo sprawuje nadzór nad warunkami wykonywania pracy. Jak wyjaśniono w literaturze, przepis obejmuje zarówno aspekt stanowienia prawa, jak i element nadzoru państwowego nad warunkami pracy, a zatem „obowiązek zapewnienia efektywnego mechanizmu wykonywania w praktyce wszelkich racjonalnych działań, również przez wyspecjalizowane swoje agendy”. Lech Garlicki zwraca uwagę, że „szczególną formą realizowania ochrony pracy musi być państwowy nadzór nad warunkami wykonywania pracy. Nie chodzi tu tylko o nadzór nad zapewnieniem bezpiecznych i higienicznych warunków pracy - nakaz ich zagwarantowania wynika odrębnie (i bardziej kategorycznie) z art. 66 ust. 1 i nie miałoby sensu zamieszczenie w konstytucji drugiego przepisu o identycznej treści. Pojęciu «warunków pracy», tak jak użyto go w art. 24, należy nadać znaczenie szersze, odnosząc je do «ogółu praw i obowiązków osób wykonujących pracę oraz podmiotów zatrudniających»" ${ }^{17}$.

Nie ulega wątpliwości, że zgodnie z obowiązującym ustawodawstwem to właśnie Państwowa Inspekcja Pracy pełni rolę państwowego nadzoru nad warunkami wykonywania pracy. W piśmiennictwie wyrażono pogląd, zgodnie z którym działanie inspekcji pracy znajduje „pośrednie umocowanie w art. 24 Konstytucji RP, który wskazuje, iż państwo

17 Por. L. Garlicki, [w:] Konstytucja Rzeczypospolitej Polskiej. Komentarz², I, red. L. GARlicki, M. Zubik. 
sprawuje nadzór nad warunkami wykonywania pracy"18. W ocenie Dariusza Makowskiego państwowy nadzór nad warunkami wykonywania pracy jest rozwinięciem zasady ochrony państwa nad pracą ${ }^{19}$. Podobny pogląd wyraża Tadeusz Zieliński, pisząc, że ochrona pracy w znaczeniu konstytucyjnym „obejmuje ogół gwarancji prawnych, jakie organy inspekcji pracy zapewniają pracownikom w stosunkach pracy"20. Zwraca się przy tym uwagę, że podstawy prawne działania PIP zostały określone w kodeksie pracy, którego art. $18^{4} \$ 1$ stanowi, że nadzór i kontrolę przestrzegania prawa pracy, w tym przepisów i zasad bezpieczeństwa i higieny pracy, sprawuje Państwowa Inspekcja Pracy ${ }^{21}$.

Mając na uwadze przepisy Konstytucji, należy dojść do wniosku, że nadmiar uprawnień delegowanych inspektorom pracy może utrudnić działalność nadzorczą państwa nad warunkami pracy. W takiej sytuacji istnieje ryzyko naruszenia norm konstytucyjnych. I chociaż zgodzić się należy z powszechnym poglądem, że pojęcie warunków pracy, o których mowa w art. 24, nie zostało wyjaśnione i ma szeroki charakter, to jednak nadmiar uprawnień może uniemożliwić wykonywanie zadań przez inspekcję. Z punktu widzenia wymogów ustawy zasadniczej kompetencje Państwowej Inspekcji Pracy nie mają nieograniczonego charakteru. Wymagają one od ustawodawcy zwykłej powściągliwości i namysłu przy konstruowaniu nowych uprawnień.

5. Zadania PIP wedŁug ustawy z 2007 R.

Genezy uchwalenia nowej ustawy z 13 kwietnia 2007 r. o Państwowej Inspekcji Pracy upatruje się w potrzebie objęcia nadzorem państwa nowych zjawisk pojawiających się na rynku pracy. W okresie wejścia w życie ustawy wiązało się to z koniecznością kontroli legalności zatrudnienia

18 Por. T. Toutsolt, Państwowa Inspekcja Pracyjako gwarant konstytucyjnej zasady ochrony pracy, «Studia z Zakresu Prawa Pracy i Polityki Społecznej» 1/2015, s. 465 i n.

19 D. Mакошsкi, Inspekcja pracy..., s. 59.

20 Por. T. Zieliński, [w:] Komentarz do kodeksu pracy, red. L. Florek, Warszawa 2005, s. 244.

${ }^{21}$ Por. T. Toutsolt, op. cit., s. 465 i n. 
i innej pracy zarobkowej. Od tego czasu inspektorzy dokonują kontroli całkowicie nowych sfer na rynku pracy, włącznie z przestrzeganiem przepisów ustawy o minimalnym wynagrodzeniu za pracy ${ }^{22}$ i zakazie handlu w niedzielę ${ }^{23}$. Lista zadań inspektorów pracy konsekwentnie powiększa się z uwagi na wejście w życie nowych przepisów.

Na mocy art. 1 ustawy o PIP jest ona organem powołanym do sprawowania nadzoru i kontroli przestrzegania prawa pracy, w szczególności przepisów i zasad bezpieczeństwa i higieny pracy, a także przepisów dotyczących legalności zatrudnienia i innej pracy zarobkowej w zakresie określonym w ustawie. $\mathrm{W}$ piśmiennictwie wyjaśniono, że Państwowa Inspekcja Pracy jest organem „w ogólnoprawnym, abstrakcyjnym sensie, tzn. stanowiącym wyodrębniony, bezosobowo ujęty podmiot [...], ustanowiony dla określonych celów i będący adresatem wskazanych w ustawie zadań i funkcji” ${ }^{24}$.

Zgodnie z art. 10 ust. 1 ustawy o PIP do jej zadań należy: nadzór i kontrola przestrzegania przepisów prawa pracy, w szczególności przepisów i zasad bezpieczeństwa i higieny pracy, przepisów dotyczących stosunku pracy, wynagrodzenia za pracę i innych świadczeń wynikających ze stosunku pracy, czasu pracy, urlopów, uprawnień pracowników związanych z rodzicielstwem, zatrudniania młodocianych i osób niepełnosprawnych. Inspekcja sprawuje kontrolę legalności zatrudnienia, innej pracy zarobkowej, wykonywania działalności oraz kontrolę przestrzegania obowiązku: informowania powiatowych urzędów pracy przez bezrobotnych o podjęciu zatrudnienia, innej pracy zarobkowej lub działalności, opłacania składek na Fundusz Pracy, dokonania wpisu do rejestru agencji zatrudnienia działalności, której prowadzenie jest uzależnione od uzyskania wpisu do tego rejestru, prowadzenia agencji zatrudnienia zgodnie $\mathrm{z}$ warunkami określonymi w przepisach o promocji zatrudnienia i instytucjach rynku pracy, prowadzenia działalności

22 Por. ustawę z 10 października 2002 r. o minimalnym wynagrodzeniu za pracę (tekst jedn.: Dz. U. z 2018 r. poz. 2177).

23 Por. ustawę z 10 stycznia 2018 r. o ograniczeniu handlu w niedziele i święta oraz w niektóre inne dni (Dz. U. poz. 305).

24 Por. J. Jagielski, [w:] M. Gersdorf, J. Jagielski, K. Rączka, Komentarz do ustawy o Państwowej Inspekcji Pracy, Warszawa 2008, s. 17. 
przez podmioty, o których mowa w art. 18c ustawy z 20 kwietnia 2004 r. o promocji zatrudnienia i instytucjach rynku pracy, zgodnie z warunkami określonymi w art. 19c, 19d, 19fa, 19ga, 85 ust. 2 i art. 85a tej ustawy. Istotny obszar uprawnień inspekcji dotyczy podejmowania działań polegających na zapobieganiu i ograniczaniu zagrożeń w środowisku pracy, a w szczególności: badania okoliczności i przyczyn wypadków przy pracy oraz kontroli stosowania środków zapobiegających tym wypadkom, analizowanie przyczyn chorób zawodowych oraz kontroli stosowania środków zapobiegających tym chorobom. Inspekcja jest zobowiązana do podejmowania działań prewencyjnych i promocyjnych zmierzających do zapewnienia przestrzegania prawa pracy, a także współdziałania $\mathrm{z}$ organami ochrony środowiska $\mathrm{w}$ zakresie kontroli przestrzegania przez pracodawców przepisów o przeciwdziałaniu zagrożeniom dla środowiska. Przedłużeniem uprawnień kontrolnych w zakresie przestrzegania prawa pracy jest prawo wnoszenia powództw przez inspektorów pracy, a za zgodą osoby zainteresowanej - uczestnictwo w postępowaniu przed sądem pracy, w sprawach o ustalenie istnienia stosunku pracy. Konsekwentnie przyjęto ponadto, że PIP ma za zadanie opiniowanie projektów aktów prawnych z zakresu prawa pracy.

Nowe obowiązki inspekcji wiążą się z wykonywaniem zadań określonych w ustawie z 10 czerwca 2016 r. o delegowaniu pracowników w ramach świadczenia usług (Dz. U. poz. 868), w tym udzielanie porad w celu wspierania równego traktowania obywateli państw członkowskich Unii Europejskiej i państw członkowskich Europejskiego Stowarzyszenia Wolnego Handlu (EFTA) - stron umowy o Europejskim Obszarze Gospodarczym, którzy korzystają z prawa do swobodnego przepływu pracowników oraz członków ich rodzin. Jak wyjaśniono w piśmiennictwie, zakres porad udzielanych przez PIP w znacznym zakresie wykracza poza sprawy należące do problematyki prawa pracy. Inspektorzy wyjaśniają bowiem kwestie dotyczące na przykład dostępu do przylepów podatkowych, zasobów mieszkaniowych oraz kształcenia.

Niektóre z kompetencji inspekcji nie w pełni przystają do pełnionych przez nią funkcji. Do takich zadań należy w szczególności kontrola spełniania obowiązków, o których mowa w art. 23r ust. 3 i 4 ustawy z 10 kwietnia 1997 r. Prawo energetyczne. Powołany przepis stanowi, 
że w ramach realizacji zadań lub kontroli prowadzonych na zasadach i w trybach określonych w odrębnych przepisach: Szef Agencji Bezpieczeństwa Wewnętrznego, Szef Krajowej Administracji Skarbowej, Prezes Agencji Rezerw Materiałowych, Prezes Urzędu Dozoru Technicznego, Dyrektor Transportowego Dozoru Technicznego, Inspekcja Handlowa, Państwowa Inspekcja Pracy oraz organy: Policji, Prokuratury, Inspekcji Ochrony Środowiska, Państwowej Straży Pożarnej, nadzoru budowlanego, administracji miar i Państwowej Inspekcji Sanitarnej kontrolują spełnienie obowiązku: 1) posiadania koncesji, w jakim dotyczą paliw ciekłych; 2) wpisu do rejestru podmiotów przywożących; 3) zgłoszenia do Prezesa Urzędu Regulacji Energetyki infrastruktury paliw ciekłych.

Przegląd uprawnień PIP prowadzi do wniosku, że zadania inspektorów zostały $\mathrm{w}$ istotny sposób poszerzone w zakresie przedmiotu działania, wymagań merytorycznych i kompetencji inspektorów pracy oraz wyzwań organizacyjnych. Co ważne, zmiany te nastąpiły pomimo niezmienionego zasadniczo zasobu kadrowego i zwiększenia się liczby podmiotów podlegających kontroli. Ostatnie zmiany dotyczące uprawnień PIP zmierzają w kierunku uczynienia z niej organu „wszechkontroli”. W konsekwencji tak szerokiego ujęcia zadań powierzonych inspekcji istnieje ryzyko osłabienia głównych funkcji, a tym samym naruszenia wymogów konwencji MOP nr 81. Jak słusznie zauważono w doktrynie, następstwem zwiększenia zadań PIP jest wzrost oczekiwań w zakresie kompetencji i wiedzy inspektorów pracy, która powinna wykraczać poza typowe problemy dotyczące prawa pracy i zatrudnienia ${ }^{25}$. Doprowadziło to do zmian w organizacji pracy inspekcji w celu podziału na określone specjalizacje. Główny Inspektor Pracy przyznaje, że obecnie inspektorzy pracy stoją przed zupełnie nowymi wyzwaniami. „Nie jest już możliwe, aby jeden inspektor mógł zajmować się całym spektrum zagadnień, jakimi zajmuje się inspekcja pracy. Konieczny jest podział prac, specjalizacja i wzajemna współpraca"26.

25 Por. D. Makowski, Aktualne kierunki legislacji dotyczacej Państwowej Inspekcji Pracy - wybrane problemy, [w:] Prawo ochrony pracy - współczesność i perspektywy rozwoju, red. T. WyкA, M. Mielczarek, Warszawa 2017, s. 116.

26 Por. R. Giedrojć, op. cit., s. 44. 


\section{Podsumowanie}

Nie ulega wątpliwości, że zadania Państwowej Inspekcji Pracy nie mogą być ani nadmierne, ani tym bardziej przypadkowe. Chaos w obrębie zadań inspekcji może prowadzić do osłabienia sprawowania funkcji ochronnej państwa nad warunkami pracy. Niestety, z szeregu uprawnień inspekcji wyłania się niezbyt jasny obraz zadań i roli PIP. Nie bardzo wiadomo, czy misja inspekcji zmierza w kierunku budowania z niej organu wspierającego, czy raczej policyjnego. Ta ostatnia wynika szczególnie $z$ delegowania zadań polegających na kontroli wysokości wynagrodzeń i respektowania przez przedsiębiorców zakazu handlu w niedzielę. Niepokojące jest również przekazywanie zadań, które nie mieszczą się w typowych funkcjach wykonywanych przez PIP. Z punktu widzenia ochrony pracy należy rozważyć, czy usytuowanie kompetencji związanych z podejmowaniem działań polegających na zapobieganiu i ograniczaniu zagrożeń w środowisku pracy dopiero na ósmym miejscu katalogu zadań PIP jest właściwe.

\section{Znaczenie kontroli Państwowej Inspekcji Pracy dLA ochrony ŻYCIA I ZDROWIA PRACOWNIKÓW}

\section{Streszczenie}

Zadania Państwowej Inspekcji Pracy powinny być zgodne z funkcjami, które wypełnia. Jednym z konstytucyjnych zadań państwa jest sprawowanie nadzoru nad warunkami pracy. Ważną rolę w tym zakresie pełni PIP. Także konwencja MOP nr 81 określa główne uprawnienia inspekcji. Poszerzenie zadań nie może prowadzić do ograniczenia jej kluczowych funkcji. Niestety, od lat utrzymuje się trend polegający na zlecaniu inspekcji nowych zadań, co może negatywnie wpływać na wykonywanie przez nią zadań w zakresie ochrony pracy. 
Poland's National Labour Inspectorate AND its Work for the Protection of Employees' Life and Health

\section{Summary}

The Polish state institution Państwowa Inspekcja Pracy (the National Labour Inspectorate) conducts supervisory operations which should be consistent with the purposes for which it has been founded. One of the state's constitutional tasks is to supervise working conditions. The Inspectorate plays an important role in this area. A definition of the Inspectorate's main powers to inspect workplaces is provided in the ILO's Convention 81. New tasks added to the Inspectorate's duties should not impede the performance of the main purposes for which it was founded. Unfortunately, for years we have been observing a tendency to encumber the Inspectorate with more and more new duties, which may have a detrimental effect on the work it is doing for the inspection of working conditions in Poland.

Słowa kluczowe: Państwowa Inspekcja Pracy; ochrona pracy; prawo pracy; Konstytucja; konwencja MOP nr 81.

Keywords: National Labour Inspectorate; labour protection; labour law; the Polish Constitution; ILO Convention 81.

\section{Literatura}

Garlicki L., [w:] Konstytucja Rzeczypospolitej Polskiej. Komentarz², red. L. GARLICKI, M. ZuBIK, I, «Lex».

GIEDRojĆ R., Rola Państwowej Inspekcji Pracy w służbie człowiekowi pracy - zadania i wyzwania XXI w., [w:] Nauka i praktyka w służbie człowiekowi pracy: Inspekcja Pracy - wyzwania przyszłości, red. A. MusiaŁA, Poznań 2017. Inspekcja pracy $w$ Polsce $w$ latach 1954-1964. Sprawozdanie ze stanu bezpieczeństwa i higieny pracy, Warszawa 1967.

Jagielski J., [w:] M. Gersdorf, J. JAgIelski, K. RąCzKa, Komentarz do ustawy o Państwowej Inspekcji Pracy, Warszawa 2008.

KLотт M., Inspekcja pracy w Polsce, Warszawa 1937. 
KozŁowski T., Geneza Państwowej Inspekcji Pracy - uprawnienia inspektora pracy wczoraj i dziś, [w:] Nauka i praktyka $w$ stużbie człowiekowi pracy: Inspekcja pracy - wyzwania przyszłości, red. A. MusiaŁA, Poznań 2017.

Laskowski J., Dorobek i kierunki doskonalenia działalności w zakresie ochrony pracy, [w:] 70 lat inspekcji pracy w Polsce, Warszawa 1989.

Mакошsкi D., Aktualne kierunki legislacji dotyczacej Państwowej Inspekcji Pracy - wybrane problemy, [w:] Prawo ochrony pracy - współczesność i perspektywy rozwoju, red. T. WyкA, M. Mielczarek, Warszawa 2017.

MAкоwski D., Inspekcja pracy jako instytucja państwowego nadzoru nad przestrzeganiem prawa pracy, Łódź 2017.

MaZurkiewiCz A., Czego nas ucza wypadki przy pracy, Warszawa 1957.

Święcicki M., Prawo pracy, Warszawa 1968.

Schubert W., Ochrona pracy. Studium społeczno-prawne, Warszawa 1966.

Toutsolt T., Państwowa Inspekcja Pracy jako gwarant konstytucyjnej zasady ochrony pracy, «Studia z Zakresu Prawa Pracy i Polityki Społecznej» 1/2015. ZIELIŃski T., [w:] Komentarz do kodeksu pracy, red. L. FloReK, Warszawa 2005. 